\title{
EDUCATION AND STATE FORMATION REVISITED
}

\author{
Andy Green
}

The origins of national education systems have constituted one of the chief preoccupations of educational historiography during the last twenty years and, latterly, state formation has offered one of the major explanatory paradigms. Versions of this approach have been developed in a number of studies of educational development in Australia, Canada, Sweden, Prussia, Britain, and elsewhere (Miller, 1986; Curtis, 1988; Melton, 1988; Boli, 1989; Green, 1990; Davey and Miller, 1990). Most of these originated in research begun in the early and mid-1980s, some ten years ago. The 1993 conference plenary of the Australian, New Zealand, and Canadian History of Education Societies thus offered an appropriate time and place to re-assess current directions of research in this field.

\section{The Search for a New Problematic}

One way to start such a review is to ask why a number of historians of education should have embarked upon similar avenues of research at about the same time. What prompted a range of historians, in, for the most part, different locations and often with somewhat different intellectual formations, simultaneously to start asking a new set of questions about the origins of mass education?

I would like to suggest that there were at least two common interests which broadly lay behind these new developments. The first of these was a common desire to understand better the complexity of power relations obtaining between the state and its subjects/citizens, between social classes, and between men and women, and the implications of this for the formation of mass education systems. The second, and related, concern was the desire to explain the uneven historical development of national education systems in different countries, including those pioneering systems which emerged first under the eighteenth-century absolutist states.

In a sense the 'state formation' problematic (or the 'educational state' as Curtis calls it) can be seen as a second wave of historical revisionism which follows on from (and reacts to) the work of the American 'Revisionist' school in the 1960s and 1970s, and most particularly that of Michael Katz, its pre-eminent exponent. Taking their lead from Bernard Bailyn's path-breaking Education in the Forming of American Society (1960), and no doubt influenced by the contemporary educational catastrophism of Kozol and others, U.S. educational historians 
of this period sought to debunk the rather historicist, Whiggish accounts of nineteenth-century education as the triumph of democratic idealism and to replace them with a narrative which recognized the class nature of the ideals pursued by the early pioneers of state education. Their critique was widely accepted and there is little need to remind ourselves of the vitality and power of the work produced by Katz, Bowles and Gintis, and others during this period.

However, the work on the educational state dates from a later period, by which time historians were preoccupied with new concerns and aware of the limitations of the early revisionist paradigm. By 1976, Katz (1976) had already declared his uneasiness with a 'social control' theory which presented state education as a one-way imposition from above on reluctant urban working-class populations. Both he and Bowles and Gintis, in a later self-critique, were now looking for a more mediated or dialectical way of construing the complex and reciprocal nature of power relations, and like many historians were increasingly attracted to Gramscian notions of hegemony as a means to do this. Much of the recent work under discussion takes off, I believe, from this point, driven by a desire to find more complex and nuanced ways of understanding the power relations involved in schooling. Bruce Curtis has used Foucauldian discourse theory to analyze the dispersal of power within the Canadian educational state; Ian Davey and Pavla Miller have used theories of patriarchy and family formation to understand a crucial aspect of state - and educational-state-formation; and I have worked primarily with Gramscian notions of hegemony to explain the differing relations between the state and schooling in different societies.

The second factor which encouraged the development of new theoretical approaches was the need to explain the uneven historical development of national education systems. In her major comparative work, The Social Origins of Education Systems (1979), Margaret Archer had clearly pointed out how inadequate were existing theories of educational change for explaining the differential timing and form of educational development across a range of countries. Theories which linked the rise of national education systems with industrialization and urbanization, in particular, faced considerable difficulties in explaining why it was that the first national systems emerged in pre-industrial and largely rural societies, like Prussia, Austria, and France, whilst in other countries, like England, such developments largely post-dated industrial take-off and widespread urbanization. Clearly a new approach was needed. Margaret Archer's own solution was to focus the question on the process of institutional change, putting the interaction of educational interest groups at centre stage. This certainly brought back into the historical equation the state dimension which David Tyack (1986) was later to argue had been overly neglected by the revisionists. What it did not do was provide any kind of theory of the state.

The work on education and state formation thus arose partly as a way of dealing with these two sets of problems. However, it was also driven and facilitated by two other contemporary factors. The role of the state in education, and indeed in all other areas of life, had been increasingly problematized since the late 1970 s by the rise of the new right with its neo-liberal philosophy of 
'rolling back the frontiers of the state,' as it was once described by Margaret Thatcher. The growing ascendancy during the 1980s, at least in the Englishspeaking world, of a new free-market education ideology, naturally challenged historians to reconsider the role of the state in education in former times, and for those of us not convinced of the viability of a free market in education, to question carefully the claims of neo-liberal historians, like West, about the advantages of laissez-faire policies in nineteenth-century England. Indefensibly 'presentist' as this motivation may seem to some historical purists, there can be no denying that it has been a powerful motivating factor.

If this was the agenda, what made it possible in the 1980s to look for new ways of explaining educational change were the new analytical tools provided by Foucauldian discourse theory and state formation theory, both of which were indebted, in their different ways, to the revival of Gramsci and his seminal writings on the educational role of the state. A key moment in this regard was clearly the publication in 1985 of Corrigan and Sayer's book, The Great Arch: English State Formation as Cultural Revolution, which can be seen, in a sense, as a history of the various ways in which one national state throughout the ages has educated its subjects into their national class and gender roles.

\section{The Critique of Older Paradigms}

Before moving on to discuss the 'state formation' problematic itself, it may be worth dwelling for a moment on some of the other classic versions of educational development that preceded it and upon which it seeks to improve. The three most important of these are: 1) Whig or liberal theory; 2) structural functionalism; and 3) neo-Marxist theories of urbanization and proletarianization. Where does the state formation argument leave these other explanations of the origins of mass schooling?

\section{1) Whig Theory}

The Whig account of educational development in the nineteenth century has been under sustained attack from educational historians since the 1960s on a number of counts. The American 'revisionists' (Katz, 1976) criticized the histories of Elwood Cubberley and his ilk for the allegedly historicist and mythological character of their narratives of educational progress as triumphant humanitarian idealism; Davey and Miller (1990) have shown how gender-blind are the notions of 'rights' and 'democracy' employed in such accounts; and others (Green, 1990; Melton, 1988) have argued the inadequacy of such models for explaining educational development in continental Europe. Post-modernists generally have been unremittingly hostile to all meta-narratives, particularly 
those stemming from the eighteenth-century western European Enlightenment, and for a post-modern educational historiography, Whig narratives of educational progress would, no doubt, be complete anathema. My own view is that the 'Whig' version is inadequate, though not because it is historicist, since all historiography starts from the present; not because it represents a 'meta-narrative,' since historians must explain and interpret; and not even because it talks of 'progress,' since I share the view that educational change in the nineteenth century can broadly be described as progress; the Whig version is inadequate because it does not explain what we know of educational change in the eighteenth and nineteenth centuries in a number of different countries. However, there are issues raised in the 'Whig' version which would need to be addressed in any more adequate historical account.

The classic Whig version of history links gradual political democratization with liberal theories of freedom and is strongly Protestant in orientation. According to this perspective, mass education was first stimulated by the Reformation, with the recognition by Protestants of the 'proselytizing' potential of schooling, and thereafter developed first and farthest in the Protestant countries of northern Europe and the Puritan states of the north-eastern United States. The enormous advances of the nineteenth century were the product of this early impulse, coupled with the intellectual thrust of the Enlightenment, and of the gradual secular movement towards political democracy, under the banner of liberal capitalism, during the nineteenth century. Each element in this explanation would seem to me deeply problematic, although I have no doubt that the questions that it poses are important. Let me say a few words about each.

Religion and the churches clearly played the major part in the development of schooling in the sixteenth, seventeenth, and eighteenth centuries and continued to be a powerful force thereafter. However, the nineteenth-century national education system was not just a linear development of church schooling but rather a major departure from it; it was an institution sui generis, developed precisely to break the clerical domination of schooling and to serve the broader interests of state and civil society. To explain its origins we must therefore look beyond religion and the churches as the determining forces.

The influence of Enlightenment philosophy clearly offers a more likely candidate for the ideological basis of nineteenth-century mass education. Without the philosophical empiricism of Locke and the rationalist optimism of the French Philosophes, it is hard to imagine what educational ideologies would have provided the ideological underpinning of the educational theories of the nineteenth-century reformers. Locke's empiricism suggested the predominance of nurture over nature and thus the potential for universal education; the eighteenthcentury theories of human rights provided a reason for educating everyone; and the materialist psychology of Hartley and Condillac, with its associationist theory of the memory, suggested that any mind could be developed through methodical pedagogic techniques. No doubt the cultural humus of the Enlightenment and the revolutionary era did provide an essential condition for the development of emancipatory theories of education. However, as we know, nineteenth-century 
schools, particularly those for the popular classes, rarely reflected these ideals, and only the most naively idealist of histories could present Enlightenment ideology as the prime mover behind the development of national education systems.

The third element of the 'Whig' triad is 'democracy' and the argument that it was the gradual process of democratization which lay behind the development of mass schooling. This, it seems to me, is the most vulnerable of the "Whig history' arguments since it is, for most of the countries in question at least, the most anachronistic. National education systems were for the most part imposed from above and, initially, owed little to popular agitation. They were first pioneered in continental Europe during the age of absolutism, typically through the efforts of 'enlightened despots' like Frederick the Great in Prussia and Maria Theresa in Austria. They were typically consolidated after the French Revolution in post-absolutist constitutional monarchies and republics which were essentially pre-democratic, and the motive for their creation generally had more to do with controlling and containing popular forces than with empowering and emancipating them. There were, of course, radical traditions in Europe, from Jacobinism to early socialism, which did link education with democracy and emancipation, but it was not generally their notions which inspired those who actually implemented school reforms, and nor, it must be said, were their notions fully democratic. As Davey and Miller have shown (1990), notions of rights, citizenship, and social contract rarely included women as equals. Rousseau's plans for the education of Sophie were very different from his plans for Émile, and even Jacobins like Lepelletier, who wanted girls educated alongside boys, thought girls needed less time in school (Green, 1990).

During the last decades of the nineteenth century, when a number of European states had begun to enfranchise sections of the male working class, and when that class had at last become a decisive force in formal politics, we can increasingly see educational reform as part of a process of democratization, and a major object of popular struggle. In a few nations which had an extended franchise from earlier in the century, as in the U.S.A., one can argue the connection for an earlier period. However, in most instances where national education systems were consolidated during the period from 1770 to 1840 , this was not so much part of a democratization process, as it was an effort by various ruling classes to contain or forestall burgeoning democratic forces. Even in the U.S.A. and Canada, as Kaestle and Curtis have shown, mass education was seen more often as a way of erecting a bulwark against the potential anarchy of rising democracy than as a way of empowering popular movements.

In his recent book, New Citizens for a New Society (1989), John Boli clearly disagrees with this point of view, at least in relation to the development of state schooling in mid-nineteenth-century Sweden. Noting, quite correctly, that this development in Sweden predated significant urban and industrial development, Boli sets out to show that mass schooling was part of the process of institutionalizing the modern state through the production of a new type of rational citizen. 'By the nineteenth century,' he writes, 'the corporate structure of estate society 
had been displaced by a new institutional framework in which the individual and the polity were the only primordial social unit. In this framew ork every individual was deemed a locus of sovereignty and therefore qualified to become an enhanced, empowered participant in the collective enterprise of constructing a progressive, just, righteous and humane society' (p. 250). Schooling was the only force capable of producing these new citizens and the 1842 statute which mandated folk schools in every parish and made education compulsory is thus seen as a necessary expression of this historical imperative. The system created was, according to Boli, characterized by: universality, equal opportunities, standardization, and individualism. The creation of co-educational elementary schools with standardized curricula is taken as evidence that the reforms were motivated by democratic egalitarianism.

The main problem with this account, it seems to me, is that the process of state formation occurring in early nineteenth-century Sweden is given a democratic and egalitarian gloss that is utterly anachronistic. There were, certainly, unique aspects of Swedish social development which tended to reduce the visibility of class conflict. As Perry Anderson (1974) has illustrated, Swedish absolutism had been unique in combining an independent, non-servile peasantry, usually a feature of western absolutisms, with nugatory towns, as in eastern absolutisms. What is more, it was distinctive in its inclusion of a separate peasant estate within its four-curia system. Under the constitutionalist monarchy of the first half of the nineteenth century, Swedish society continued to exhibit a relatively static equilibrium with low-pressure class conflicts. However, the ideology of that society is surely not described accurately by adjectives such as individualist, democratic, and egalitarian. The Riksdag was still based on the four-estate system of representation until 1866 when it was replaced by a bi-cameral parliament with a twenty-one percent male franchise. In between the state and the individual in this pre-democratic society there still stood the corporate institutions like the church and the guilds, privileged by compulsory membership until 1846. As far as the terms are historically useful, one may see early nineteenth-century Sweden as in transition to a society based on individual contract, but at this stage the concept of individual citizenship was based on neither democratic nor egalitarian principles, and nor was education. The school system, which, as Boli admits, was created in the teeth of peasant apathy, was clearly differentiated, with a separate system of private schools for the middle and upper classes forming a separate ladder from the folkskolar system. Participation in this system was extremely unequal. Boli himself cites Johansson's data for the Vasterbotten parish at the mid-century which show that school attendance varied by a factor of twelve between children of civil servants (fifty-one percent) and children of tenant farmers (four percent) (Boli, 1989, p. 234). 


\section{2) Industrialization}

If liberal theory has undergone a belated, and, I would argue, unsuccessful, revival in the work of John Boli, the industrialization theory, on the contrary, seems to have been allowed to rest in peace in recent years. It is now widely accepted amongst educational historians (Archer, 1979; Melton, 1988; Boli, 1989; Green, 1990; Davey and Miller, 1990) that the development of national education predates industrialization in many countries and that Britain was exceptional in postponing the development of a national system until after the first stage of industrialization had been accomplished. Furthermore, it now seems fairly clear that whilst education and new skills became economic necessities in the later stages of industrialization, during the first decades of the nineteenth century, when several national education systems were established, the demand for new industrial skills was fairly limited and not one of the main motivations behind educational development. This is not to say that there was no occupational rationale for schooling, but rather that the occupations targeted were not generally industrial. Governments were concerned more with educating political leaders, administrators, officers, soldiers, and loyal subjects rather than scientists, technologists, production engineers, and skilled workers. By the 1830s, of course, there were a growing number of more forward-looking politicians, industrialists, and educational advocates in France, America, Prussia, and elsewhere, who saw education, and particularly technical education, as a way of promoting industrialization, but by that time national education systems were already well under way. If we are looking at the origins of national education, rather than at its later development, then industrialization is clearly not the significant factor.

\section{3) Proletarianization and Urbanization}

Neo-Marxists like Michael Katz have long argued a connection between the development of mass education and the proletarianization and urbanization of populations in the north-eastern states of the USA. Put simply, the argument is that the rapid urbanization in the North-East between 1820 and 1860, fuelled by large-scale immigration and internal migration, and coupled with the gradual transition to wage labour in urban and rural areas, led to unprecedented class and community conflicts and a crisis of youth socialization. Educational reform was primarily a way of containing and controlling these forces through the imposition of moral discipline by the WASP middle class. The thesis is immensely powerful as an explanation of urban educational reform and offers a realistic assessment of the motivations of reformers like Horace Mann who expressed their intentions in ways that can be read in this fashion. The argument also can be effectively applied to the situation in England in the conflict-ridden 1830s and 1840s where educational reformers were equally prone to express their intention in terms of moral and social policing (Green, 1990). 
However, the thesis is not easily generalizable outside these areas and this period and therefore can supply no more than one part of a more general comparative theory of educational development. The thesis fits well with the situation in the urban north-eastern areas of the U.S.A. but has less purchase on the rapid educational developments in some predominantly rural areas like the mid-West. It is worth remembering that even by 1860 , eighty-four percent of the population in the U.S.A. lived in communities of fewer than 8,000 and the majority still worked as independent farmers (Green, 1990, p. 64). By focusing on developments in the urban north-east during the era of reforms (1830-60), Katz not only underplays developments in rural areas but also rather foreshortens the process of educational change in the U.S.A., thereby missing the important contribution of the Early Republic to the construction of public education.

In relation to the origins of national education in continental Europe, the urbanization/proletarianization thesis would seem to face even greater problems. Here national education systems were first consolidated at a time when all the countries concerned were predominantly rural and when the majority of the working population had yet to be converted into wage labourers. By 1855 , well after the construction of their national systems, only twenty-seven percent of the French population lived in towns, compared with thirty percent in Bavaria, thirty-five percent in Saxony, twenty-eight percent in Prussia, and ten percent in Sweden (Green, 1990, p. 55). The majority of the active population in all these countries still worked in agriculture, mostly as independent farmers, and of those who worked in industry, the majority were artisans rather than fully proletarianized waged labourers.

However, an argument can be made for connecting the early stages of proletarianization with the genesis of national schooling if we take this process to include the development of 'proto-industrial' workers in the eighteenth century. James Melton, in his impressive work on the origins of state schooling in Prussia, has argued that a number of factors in eighteenth-century Prussia, including the growth of proto-industrial production, the decline of the guild system, the proliferation of absentee landlords and landless rural poor, and the de-feudalization of the peasantry, contributed towards a crisis of social authority, particularly in relation to children, for which compulsory schooling was seen as an effective antidote. Drawing on the work of Melton, Levine, and more recent feminist historiography, Davey and Miller have effectively demonstrated how these changes in production relations, and their associated family forms, can be seen as constituting a breakdown of the patriarchal authority traditionally vested in usually male heads of households. The development of national school systems from the eighteenth century onward can thus be seen as a response to this erosion of patriarchal power over children and an attempt to reconstitute patriarchal authority through the state.

This seems to me to be a powerful argument and a crucial dimension of any account of education and state formation during the seventeenth, eighteenth, and nineteenth centuries. However, while it clearly contributes towards the analysis of the origins of the pioneer continental education systems, it is not clear to me 
how this argument can be used to explain the uneven development of education systems. England was centuries in advance of continental Europe in transformations on which this account hinges - in the transition to a 'free' peasantry (Macfarlane, 1979) and then to agricultural waged labour and in the spread of proto-industrial household production-and thus presumably also experienced the erosion of patriarchal authority earlier; yet this did not apparently generate a commensurate movement towards national schooling. In their 1991 paper, Davey and Miller seek to explain this by the somewhat contradictory argument that there was less need for state schooling in Britain because the early spread of wage labour under a precocious capitalism 'provided much of its own discipline' (p. 15). In their later (1993) conference paper this argument is abandoned and the explanation now rests on an argument about the particular nature of state formation in Britain. Although it is not quite clear to me where this leaves the argument about the crisis of patriarchal authority being the prime cause of mass schooling, this focus now offers a theoretical approach to the problem of uneven development to which I will return later.

\section{Education and State Formation}

All the accounts considered clearly contain important arguments which can contribute towards an explanation of the rise of national education systems. However, they remain partial explanations and lack the power to explain the differential development of education systems in a range of different states. The argument of education and state formation represents an attempt to sketch an alternative theory which can account for these differences, particularly, it should be said, with reference to the relatively late development of a national system in England and Wales.

The key social factor, I would argue, in explaining the timing and form of the development of education systems is the nature of the state and the process of state formation. The major impetus for the creation of national education systems lay in the need to provide the state with trained administrators, engineers, and military personnel; to spread dominant national cultures and inculcate popular ideologies of nationhood; and so to forge the political and cultural unity of burgeoning nation-states and cement the ideological hegemony of their dominant classes. This inevitably entailed at different times using education to perform some of the functions suggested by existing theories. In societies undergoing the proletarianization of labour, education could be a useful tool in acclimatizing workers to waged employment whether in workshops, factories, or on the land. Equally, in regions undergoing rapid urbanization, numerous social conflicts were thrown up which it fell to schools to attempt to control and ameliorate. The break-up of traditional pre-proletarian family forms caused particular problems for youth socialization in the context of antagonistic class societies and education was frequently seen as a substitute mechanism to achieve this in ways which were 
acceptable to the dominant classes. However, it was specifically the intervention of the state which effected the formation of national education systems, and it is therefore the nature of the state in different countries which must carry the largest burden of explanation for the particular national forms and development of school systems.

The national education system developed in parallel with the modern capitalist state. The form of the national system was first prefigured in continental Europe during the absolutist monarchies of the eighteenth century. These not only developed many of the general features of the modern state-central bureaucracies, standing armies, national taxation-but they also pioneered the first moves toward public education with the provision of state funds for schooling, and the drafting of prescribed curricula and legislation on school attendance. Education was seen as an important means for furthering the mercantilist aims of the state. It was essential for providing the trained cadres for the government bureaucracy and the military and had an important role to play in generating the skills needed for the fledgling state manufacturing projects. Not least, also, it was recognized to be a powerful instrument for promoting political loyalty amongst the people and for creating a cohesive national culture after the image of the ruling class.

The nineteenth-century education system came to assume a primary responsibility for the moral, cultural, and political development of the nation. It became the secular church. It was variously called upon to assimilate immigrant cultures, to promote established religious doctrines, to spread the standard form of the appointed national language, to forge a national identity and a national culture, to generalize new habits of routine and rational calculation, to encourage patriotic values, to inculcate moral disciplines, and, above all, to indoctrinate in the political and economic creeds of the dominant classes. It helped construct the very subjectivities of citizenship, justifying the ways of the state to the people and the duties of the people to the state. It sought to create each person as a universal subject but it did so differentially according to class and gender. It formed the responsible citizen, the diligent worker, the willing taxpayer, the reliable juror, the conscientious parent, the dutiful wife, the patriotic soldier, and the dependable or deferential voter. If state formation involved using schooling to create new citizens/subjects, it was also, as Davey and Miller's work suggests, about creating clearly gendered social roles for these subjects and about fashioning new forms of patriarchal control over children. Typically, schools were entrusted with making boys into useful citizens and girls into wives and mothers who would rear the next generation of male citizens.

The formation of national systems occurred first and fastest in countries where the process of state formation was most intensive. Three historical factors have been particularly associated with this accelerated and compacted process of state formation or 'nation-building.' One has been the existence of external military threats, or territorial conflicts, which often have propelled the victim nations into vehemently nationalistic responses and deliberate actions to strengthen their state machines. Another has been the occurrence of major 
internal transformations resulting either from revolution, as in France, or from a successful struggle for national independence, as in America. In each case the country concerned has emerged from major conflagrations with an urgent task of national reconstruction, not only to repair the ruins of war but also to establish a new social order which will reflect the principles for which the struggle was originally undertaken. Lastly, there have been the situations where nations have been prompted into state-led programmes of reform to escape from relative economic underdevelopment. Where one country is significantly behind other countries economically it generally has not been possible to catch up simply by the spontaneous initiatives of individual entrepreneurs. Liberal politics have not been much use to underdeveloped countries, since they favour the already powerful (Hobsbawm, 1990), and nations which have successfully reversed histories of underdevelopment generally have done so either under the wing of other more powerful states or through concerted, centrally directed programmes of reform.

The development of national education systems has been historically closely connected with these phenomena, not only during our period here but also in the modern day where education has been a major priority of countries undergoing national reconstruction after war or successful struggles for independence. In the eighteenth and nineteenth centuries those nations which underwent this kind of state formation were most prone to develop national education and generally they did this at the precise period when the process was at its highest pitch. Militaristic state-building first propelled the eighteenth-century Prussian state into educational development and the pressures of economic advance kept the process on the boil in the next century, as absolutism gave way to constitutional bourgeois rule. Absolutism played a similar if lesser role in France. But here it was principally revolution and bourgeois social and economic reconstruction under Napoleon, and after, that fuelled a similar educational drive. In the United States, another leading country for educational reform, it was the need to consolidate a new American state after the break with England that did most to galvanize educational reform. Unlike in continental countries this was achieved less through the work of the central state and more through the initiative of individual reformers and the local state and county administrations with which they were closely allied. If the process here appears to have been based on broader democratic foundations and owed less to the étatist spirit that characterized continental development, it was still clearly understood as a means of developing the national culture and securing the political system and no less a process of organized state formation.

The development of a national education system in Japan after the Meiji Restoration of 1888 can also be understood as part of a process of intensive state formation. As Herbert Passin has written,

educational reform ranks as one of the key measures in the transformation of Japan from a feudal to a modern nation state....Through the use of uniform teaching materials and the diffusion of a national language..., 
the schools helped promote a common sense of nationhood and the displacement of regional by national loyalties. (Passin, 1965, p. 62)

During the pre-Meiji Tokugawa period, Japan had a thriving educational culture amongst the Samurai elite whose children were educated in the domaine schools run by the feudal authorities, but less than fifty percent of the population as a whole (by 1860) went to school and most of these in the privately run Terakoya basic schools. Towards the end of the Shogunate, and after the arrival of Commodore Perry in 1853, Japanese culture began to be more open to western science, but the schools remained dominated by traditional Confucian values. It was the Samurai reformers after the Meiji Restoration who sought to modernize Japan and saw education as a means of mobilizing the entire population in this process of state formation.

With the establishment of a Ministry of Education in 1871, a new education system was developed which initially drew heavily on western influences, incorporating French principles of centralized administration and American modern curricula. A later conservative backlash against westernization then led to calls for a return to traditional Japanese values in education, epitomized in the nationalistic Imperial Rescript of 1879 , which stressed the role of education in promoting loyalty to the state and the Emperor. After 1885, Japan's celebrated education minister, Mori Arinori, sought to reconcile modernity and tradition by promoting a westernized secondary education for the élite whilst preserving traditional values in popular education. Though later assassinated by nationalists, Arinori expressed his mission for education in classic nation-building terms: 'Our country must move from its third class position to second class, and from second class to first, and ultimately to the leading position amongst countries in the world' (quoted in Passin, 1965, p. 68). In the different world climate of the 1930 s, the nationalistic strain would lead to full-scale militarism and indoctrination in Japanese schools; during the Meiji period the nation-building role of education helped transform Japan from a feudal to a modern state.

\section{Canada West}

The construction of the 'educational state' in Canada West in the mid-nineteenth century provides another illustration of education as state formation but in rather a different sense from the other examples cited here, since the formative period of educational development occurred during a period of as yet unresolved struggle over colonial rule. As Bruce Curtis's book clearly demonstrates, educational reform in the period 1830-70 was inextricably tied up with struggles over the nature of the colonial state and different parties had different ideas about what kind of state they wished to promote through their educational reforms. What they had in common was a belief that education was essential for the creation of a new type of political subject whose own internalization of discipline and moral 
responsibility was seen as a pre-condition for political order in an emerging polity, which, whatever form it eventually took, would involve greater independence and more representative government. As elsewhere, the reforms were essentially constructed from above, and reflected the class aims of the dominant groups, but they cannot be construed as a crude process of imposition and unmediated social control. What Curtis demonstrates so well in his book is the process by which the reformers sought through education to 'anchor...the conditions of political governance in the selves of the governed' (p. 15). As described by Curtis, this amounted to a classic exercise in the construction of a cultural hegemony by dominant groups through education, whereby 'official knowledge presented the patriarchal, linguistic, ethical, political, economic and religious interests of the ruling class as the general interests of society' (Curtis, 1988, p. 371).

\section{England}

In England the development of education was no less a process of state formation than it was in these other countries. However, due to the particular nature of the state, and of its relationship to civil society, a national education system did not occur until relatively late compared with the other countries mentioned here. Although I do not much like the terminology, this can be seen as a question of early 'strengths' and later 'weaknesses.' Throughout the sixteenth, seventeenth, and eighteenth centuries, the British state was characterized by relative unity of its kingdom and the relative stability and durability of its institutions and ruling groups. One of the first consolidated nation-states in Europe (despite the protracted and bloody process of colonization in Ireland), the British state benefited from the early centralization of state power under the Tudors, and the advantages afforded by its geographical insularity and maritime strength, from which grew its colonial power. The early termination of absolutism through Cromwell's revolution, added to its other advantages, made possible the early development of capitalist relations in agriculture, commerce, and later, industry. During the eighteenth century, the relative absence of military conflict, combined with the economic advantages of natural resources and colonial trade, allowed capitalist development to take advantage of the home markets provided by a relatively fluid society undergoing a demographic explosion. Early industrialization could thus occur organically, from the bottom up, without excessive intervention from the state.

State formation, or 'nation-building' to use Walter Bagehot's nineteenthcentury phrase, was thus a comparatively precocious affair in Britain, and though bloody and violent at times, to be sure, occurred more gradually than in many other countries considered here. It also occurred without the enlarged, 'forcing' apparatus of the absolutist state which was so central to modernization in other countries. With a history of long-standing and relatively stable institutions and 
ruling groups to draw on, national identity did not have to be invented as in other countries where nation-building required the elaboration of various nationalist ideologies which literally had to manufacture traditions. If nationalism in other countries meant creating what Benedict Anderson calls 'imagined communities' (Anderson, 1983), Britain had no need of it, since the nation was the past. Such a state also had less need for national education during the eighteenth century, since there was not the great demand for bureaucrats and military recruits which existed in absolutist states and since the population scarcely had to be schooled in 'nationhood.'

The absence of a national education system in eighteenth-century England was thus certainly not the product of a weak state. In their conference paper, Davey and Miller refer to my argument about the late development of English national education as hinging on the "'notorious weakness" of the British state' (Davey and Miller, 1993, p. 6) but they are in fact quoting their own earlier paper (Davey and Miller, 1991, p. 8) and not myself since neither that formulation nor the argument it implies were in Education and State Formation. What I have argued, following Hobsbawm (1969), Gamble (1981), and Marquand (1988), is that the early 'strengths' of the British state and economy later became fetters on the development of a modern state and economy, but this argument applies to the period after 1860.

During the period 1815-60 it would be quite inaccurate to talk of a 'weak state' in Britain, for the creation of a laissez-faire system precisely required a strong - albeit streamlined-state to remove all the old barriers and restrictions to 'free enterprise.' The state properly described as 'liberal' or 'laissez-faire' emerged after the end of the Napoleonic Wars (although its principles derived, of course, from Adam Smith in the previous century), and then developed only gradually through deliberate state action. The term is not generally applied, as Davey and Miller appear to suggest (Davey and Miller, 1993, p. 7), to the period of Burkean reaction which followed the French Revolution. The liberal state was deliberately minimalist, or tried to be, but was not so much weak as limited in the extent of its apparatus and functions. This became a problem, I would argue, after 1860 and has remained so since, in the sense that after the so-called second Industrial Revolution, and in what later became known as the era of monopoly capitalism, successful economies came to require more effective state intervention in all spheres of life to ensure conditions of existence. Corrigan and Sayer's account of British state formation, which consciously plays down its uniquely 'laissez-faire' features, is unable to explain these later obstacles to modemization, and it is to explain this later course of development that I have stressed the English 'peculiarities.' However, whilst I would maintain that 'laissez-faire' was a defining characteristic of the British liberal state in the nineteenth century, 'weakness' was not. During the 'golden age' of Victorian capitalism, the British state certainly did not appear as 'weak,' even though it may be said to have been storing up problems for the next generations.

Education was, however, in a sense, 'weak' or 'underdeveloped' in that provision was in various respects both less extensive and less appropriate than it 
might have been to needs of the time, and compared with other comparable countries. Admittedly these 'needs' often were not generally recognized, except by the long-sighted, until later (say in the 1860s) and one may thus be accused of hindsight and anachronism in applying them to earlier periods like the 1840s and 1850s. However, there were clear social and political 'needs' for more education even at that time, as many did in fact recognize, and arguably also long-term economic needs, for even if the British economy developed rapidly in these years without improved education, the absence of that education would have consequences for the economy of the next generation.

This underdevelopment of education, I have argued, was the result of the failure to develop a national system until late in the day; this in turn was the result of the specific nature of state formation in Britain, where laissez-faire liberalism continued to provide powerful arguments against the use of the state in education.

\section{Some Conclusions}

State formation theory still seems to me to provide the most powerful analytical basis for understanding the origins of national education systems and their uneven historical development. I know of no other theory which has equal explanatory power across a range of geographical contexts and in different historical periods. However, it is, as Roy Lowe (1991) perceptively remarked in a review of Education and State Formation, very much an outline or portmanteau theory, which is to say a theory which brings together a range of other arguments. Its strength, therefore, depends very much on the elaboration of the theoretical elements within it and on the detailed way in which it is developed in different national historical contexts. Such specific studies will also, no doubt, continue to force modifications in the way we conceptualize the process of state formation, as is proper with any theory.

My own interest lies in developing the theory in relation to later historical periods, thus moving away from the origins of national systems and starting to look at how they have been elaborated in later periods as part of different processes of state formation. Currently, this involves looking at education and state formation during the Age of Empire, particularly in relation to Britain, France, Germany, and Japan. This, of course, raises a whole new set of problems in state formation in relation to nationalism, militarism, and imperialism. State formation in western Europe in the hundred years after the French Revolution was essentially about the creation of sovereign, territorially bounded nationstates. In its liberal and Mazzinian form this generally meant welding together heterogeneous populations and territories in larger units which were economically and politically viable, and which were cemented by ideologies which stressed statehood and citizenship rather than language and ethnicity, although these were sometimes called upon as was politically expedient. As we know from Hobsbawm's work (1989), nationalism took on very different guises towards the 
end of the century, stressing language and ethnicity in new racist discourses, and increasingly becoming the property of the political Right. At the end of the nineteenth century, state formation became, in many areas, empire-building; since the First World War it has often come to mean the disaggregating process of balkanization encoded in the Wilsonian doctrine of 'self-determination.' As state formation in these contexts takes on radically different forms, so the relationships between education and state formation change. If state formation is to continue to be a useful concept for explaining educational change, it is important to test its applicability in these contexts as well.

State formation theory may also be applied to issues in the contemporary history of education. There are those who argue that the historical significance of the nation-state is dwindling in the face of economic globalization, the rise of supra-national entities, and the accompanying tendencies towards regionalization, and that analyses of education which focus on the nation-state are becoming irrelevant. I would not entirely share this view. Although it is clearly important to take account of the supra-national forces shaping education systems, educational change is still determined largely by the policies adopted by national governments and this would seem likely to be the case for some time to come. What is more, whilst post-modernists and advocates of the free market see a world-wide shift in education systems away from collectivist goals and towards an individualized and privatized consumerism, there is plenty of evidence that national governments continue to use education as a means for pursuing national goals, like economic competitiveness and social cohesion, albeit influenced by global forces and supra-national entities like the European Union. This is still true in the most market-oriented societies like Britain and the U.S.A., where increasingly centralized control over schooling allows governments to use education as a tool of national policy as never before. In a different way it is also the case in the new states emerging in Eastern Europe, many of which already are using their school systems very deliberately as vehicles for nation-building. In my own recent comparative work on contemporary post-compulsory education policy, I have tried to use a state formation perspective to explain divergent national patterns (Green and Steedman, 1993), and I hope to take this further in future research.

There is still great scope for using a state formation perspective to help us understand the different historical patterns which have led to the diversity of modern education systems. 


\section{Bibliography}

Anderson, B. (1983). Imagined Communities. London: Verso.

Anderson, P. (1974). Lineages of the Absolutist State. London: Verso.

Archer, M. (1979). The Social Origins of Education Systems. London: Sage.

Bailyn, B. (1960). Education in the Formation of American Society. Williamsburg, Virginia: Institute of Early American History and Culture.

Boli, J. (1989). New Citizens for a New Society: The Institutional Origins of Mass Schooling in Sweden. Oxford: Pergamon Press.

Bowles, S. and Gintis, H. (1976). Schooling in Capitalist America. London: Routledge and Kegan Paul.

Corrigan, P. and Sayer, D. (1985). The Great Arch: English State Formation as Cultural Revolution. Oxford: Blackwell.

Curtis, B. (1988). Building the Educational State, Canada West, 1836-1871. London, ON: The Althouse Press.

Davey, I. and Miller, P. (1990). 'Family Formation, Schooling and the Patriarchal State,' in Family, School and State in Australian History, ed. M. Theobald and R.J.W. Selleck. London: Allen and Unwin.

Davey, I. and Miller, P. (1991). 'Patriarchal transformations, schooling and state formation,' paper for Social Science History Association Conference, New Orleans. London: Verso.

Davey, I. and Miller, P. (1993). 'Governance of the self, family and the state from the reformation to the age of democratic revolutions,' paper for the 1993 Conference of the Australian, New Zealand, and Canadian History of Education Societies, Melbourne.

Gamble, A. (1981). Britain in Decline. London: Macmillan.

Green, A. (1990). Education and State Formation. London: Macmillan.

Green, A. and Steedman, H. (1993). Educational Provision, Educational Attainments and the Needs of Industry. London: National Institute of Economic and Social Research.

Hobsbawm, E. (1969). Industry and Empire. Harmondsworth: Penguin.

Hobsbawm, E. (1990). Nations and Nationalism Since 1780. Cambridge: Cambridge University Press.

Katz, M. (1968). The Irony of Early School Reform. New York: Harvard University Press.

Katz, M. (1976). 'The Origins of Public Education: A Reassessment,' History of Education Quarterly 16, 4: 381-407.

Lowe, R. (1991). Review of Education and State Formation, in History of Education 20 , 4: $380-81$.

Macfarlane, A. (1978). Origins of English Individualism. Oxford: Blackwell.

Marquand, D. (1988). The Unprincipled Society. London: Macmillan.

Melton, J. Van Horn. (1988). Absolutism and the Eighteenth-Century Origins of Compulsory Schooling in Prussia and Austria. New York: Cambridge University Press.

Miller, P. (1986). Long Division: State Schooling in South Australian Society. Adelaide: Wakefield Press.

Passin, H. (1965). Society and Education in Japan. New York: Teachers' College Press.

Tyack, D. and James, T. (1986). 'State Government and American Public Education: Exploring the Primeval "Forest",' History of Education Quarterly 26, 1: 39-69. 